\title{
pH Sensitive Hydrogel Based on Poly(Acrylic Acid) and Cellulose Nanocrystals
} (Hidrogel Sensitif terhadap pH Berasaskan Poli(Asid Akrilik) Diperkuatkan Selulosa Nanohablur)

\author{
LIM SZE LIM, ISHAK AHMAD* \& AZWAN MAT LAZIM
}

\begin{abstract}
The purpose of this study was to produce a novel pH sensitive hydrogel with superior thermal stability, composed of poly(acrylic acid) (PAA) and cellulose nanocrystal (CNC). CNC was extracted from kenaf fiber through a series of alkali and bleaching treatments followed by acid hydrolysis. PAA was then subjected to chemical cross-linking using the crosslinking agent ( $N, N$-methylenebisacrylamide) in CNC suspension. The mixture was casted onto petri dish to obtain disc shape hydrogel. PAA/cellulose hydrogel with the same composition ratio were also prepared as control. The effect of reaction conditions such as the ratio of PAA and $C N C$ on the swelling behavior of the hydrogel obtained towards pH was studied. The obtained hydrogel was further subjected to different tests such as thermogravimetric analysis (TGA) to study the thermal behavior, Fourier transform infrared for functional group identification and swelling test for swelling behavior at different $\mathrm{pH}$. The cross-linking of PAA was verified with FTIR with the absence of $C=C$ double bond. In TGA test, PAA/CNC hydrogel showed significantly higher thermal stability compared with pure PAA hydrogel. The hydrogel obtained showed excellent $\mathrm{pH}$ sensitivity and experienced maximum swelling at pH7. The PAA/CNC hydrogel can be developed further as drug carrier.
\end{abstract}

Keywords: Acrylic acid; cellulose nanocrystals; hydrogel; swelling behavior

\section{ABSTRAK}

Objektif kajian ini adalah untuk menghasilkan hidrogel poli(asid akrilik) (PAA) diperkuatkan selulosa nanohablur (CNC) yang bukan sahaja sensitif terhadap rangsangan $\mathrm{pH}$ tetapi juga mempunyai sifat terma yang baik. CNC diekstrak daripada serabut kenaf melalui rawatan alkali dan rawatan pelunturan dan diikuti hidrolisis asid. Asid akrilik (AA) ditautsilangkan dengan menggunakan agen tautsilang (N,N-metilenabisakrilamid) dalam ampaian CNC. Campuran kemudian dituang ke dalam piring petri panas untuk mendapatkan hidrogel yang berbentuk cakera. Hidrogel PAA/ selulosa dengan komposisi yang sama juga telah dihasilkan sebagai kawalan. Kesan parameter tindak balas seperti nisbah PAA dan CNC terhadap sifat pembengkakan hidrogel telah dikaji. Hidrogel yang dihasilkan diciri dengan analisis termogravimetri (TGA) untuk mengkaji sifat terma hidrogel yang dihasilkan. Transformasi Fourier inframerah pula digunakan untuk mengenal pasti kumpulan berfungsi hidrogel. Selain itu, ujian pembengkakan juga telah dijalankan untuk mengkaji sifat pembengkakan hidrogel pada pH yang berbeza. Kehilangan puncak $C=C$ membuktikan bahawa asid akrilik telah berjaya ditautsilangkan kepada poli(asid akrilik). Dalam analisis TGA pula, hidrogel PAA/CNC menunjukkan kestabilan terma yang lebih baik berbanding dengan hidrogel PAA. Hidrogel yang dihasilkan adalah sensitif terhadap perubahan $\mathrm{pH}$ dan mencapai pembengkakan maksimum pada pH7. Hidrogel PAA/CNC mempunyai potensi untuk dijadikan pembawa ubat secara terkawal.

Kata kunci: Asid akrilik; hidrogel; selulosa nanohablur; sifat pembengkakan

\section{INTRODUCTION}

Hydrogel are cross-linked hydrophilic polymer capable of absorbing large amount of water or aqueous solution without dissolving in response to external stimuli such as changes in $\mathrm{pH}$, temperature, electric field and concentration of added salts (Bardajee et al. 2011; Kim et al. 2004; Yuk et al. 1992). Natural characteristics such as soft, flexible, elastic and wet nature make hydrogel a frontrunner in various fields including biomedical (Censi et al. 2011; Wang et al. 2012; Zuidema et al. 2011), metal nanoparticles preparation (Sahiner 2013), contact lenses (Sorbara et al. 2009), heavy metal ion removal (Wu \& Li 2013) and dye removal (Shirsath et al. 2013). Although many researches has been focusing on preparing hydrogel from natural occurring polymer, but the versatile properties of synthetic hydrogel had given them a distinctive advantage which in turn broaden their practical utility. There are a few methods used extensively in cross-linking hydrogel network including gamma-ray radiation (Zhou et al. 2012), photo-crosslinking (Sharifi et al. 2012), chemical cross-linking (Varga et al. 2010) and heating to form physically cross-linked gel (Hellio \& Djabourov 2006). In this study, chemical cross-linking was used due to the simplicity of reaction, does not require special instruments or modification towards monomers and form thermal irreversible hydrogel. 
Poly(acrylic acid) is a typical $\mathrm{pH}$ responsive super absorbent that is commercially available. PAA is considered as $\mathrm{pH}$ sensitive material due to the ionic repulsion between its anionic groups. PAA offer vast potential in biomedical application as it can be prepared at various concentrations, fabricated into different size and shape and other materials can be incorporated into PAA prior to gel formation (Huang et al. 2007; Kim et al. 2004). Acrylic acid monomer can be readily crosslinked or copolymerized with functional monomers such as $\mathrm{N}$-isopropylacrylamide, 2-hydroxylmethacrylate and $\mathrm{N}, \mathrm{N}^{\prime}$ methylenebisacrylamide or prepolymer such as poly(vinyl alcohol) and poly(ethylene glycol) (Arunbabu et al. 2012; Wen et al. 2001). Both swelling capacity and swelling behavior along with thermal and mechanical properties are the main criteria in hydrogel assessment as these properties will affect hydrogel usability in various applications (Janković et al. 2007) ${ }^{1717 H ~ 2 . ~ A l t h o u g h ~ P A A ~}$ possess lots of attractive properties, its poor thermal and mechanical properties limit the application of the hydrogel produced from PAA to certain extent (Needleman \& Smales 1995).

Over the last decade, researches have been conducted to modify natural fibers as a resource in the production of cellulose nanowhiskers for different applications. Cellulose is the world's most abundant naturally occurring polymer (Liu et al. 2011). Cellulose nanocrystals are rod shape highly crystalline nanometric particles that can be extracted from cellulose through acid hydrolysis to form a colloidal CNC suspension (Flauzino Neto et al. 2013; Henrique et al. 2013; Sheltami et al. 2012). In particular, this hydrolysis process uses concentrated sulphuric acid to remove the amorphous region of cellulose leaving the crystalline domains intact (Bondeson et al. 2006). CNC has attracted great attention owing to its prominent characteristics such as high tensile strength and modulus, high aspect ratio, low density and cost, biocompability and biodegradability (Chang et al. 2006; Habibi et al. 2010). Cha et al. (2012) has reported that the presence of $\mathrm{CNC}$ in hydrogel network can result in a more structured hydrogel thus increasing thermal stability of hydrogel.

The main objectives of this study were to first extract CNC from kenaf fiber follow by preparing a poly(acrylic acid) hydrogel reinforced with CNC. The treated fiber and hydrogel obtained were then characterized using FTIR and the effects of CNC loading on the swelling behavior and thermal stability of the hydrogel were studied.

\section{MATERIALS AND METHODS}

Raw kenaf bast (Hibiscus cannabinus) fibers were kindly supplied by KFI Sdn.Bhd. Sulfuric acid (98\%), sodium hydroxide $(99 \%)$, sodium chlorite $(80 \%)$, glacial acetic acid (99.5\%) and acrylic acid (99\%) were purchased from SYSTERM-chemAR (Malaysia) and Sigma-Aldrich (Germany). Laboratory grade N,N'methylenebis(acrylamide) (MBA, 99\%) and ammonium persulphate (APS, 99\%) were both purchased from
Sigma-Aldrich and were used as cross-linker and initiator, respectively.

\section{PREPARATION OF CNC}

Cellulose nanocrystals (CNCs) from kenaf were prepared by acid hydrolysis of the cellulose obtained as described elsewhere (Kargarzadeh et al. 2012). Briefly, kenaf fibers were firstly grinded and treated with $4 \% \mathrm{NaOH}$ solution for $3 \mathrm{~h}$ at $90^{\circ} \mathrm{C}$ under constant mechanical stirring and reflux condition. The alkali process was repeated for 3 times. The treated fibers were then undergone bleaching treatment with $1.7 \mathrm{w} / \mathrm{v} \%$ sodium chlorite at $\mathrm{pH} 4.5$ and $100^{\circ} \mathrm{C}$ for $4 \mathrm{~h}$ under reflux condition. The bleaching process was repeated for 4 times. The bleached fibers were then subjected to hydrolysis using concentrated sulphuric acid $(65 \%)$ to remove hemicelluloses. The reaction was carried out at $45^{\circ} \mathrm{C}$ under constant stirring for $45 \mathrm{~min}$. The hydrolysis reaction was terminated after 45 min by placing the reaction flask in an ice bath. The suspension was then washed with distilled water and centrifuged at $4500 \mathrm{rpm}$ and $10^{\circ} \mathrm{C}$. The centrifugation process is repeated until constant $\mathrm{pH}$ was obtained. It is then placed into dialysis tube and dialyzed against distilled water until $\mathrm{pH}$ was neutral. The resultant suspension was then freeze-dried to obtain nanocrystal cellulose powder.

\section{PREPARATION OF POLY(ACRYLIC ACID) / CNC HYDROGEL}

The hydrogel were prepared by free radical polymerization of AA in CNC suspension using APS as initiator. Typically, an aqueous solution of water $(25 \mathrm{~mL})$, AA (4.9 g), CNC $(0.1 \mathrm{~g})$ was prepared and the mixture was homogenized to ensure the $\mathrm{CNC}$ suspended uniformly. Ten $\mathrm{mL}$ of $1.5 \%$ MBA solution was added and the mixture was then heated on a hot plate. APS solution ( $1 \mathrm{~mL}$ of $10 \%)$ was added when the mixture reached $50^{\circ} \mathrm{C}$. The mixture was casted into a pre-heated petri dish at $60^{\circ} \mathrm{C}$. The specific compositions of the hydrogel produced were shown in Table 1 . The poly(acrylic acid) / cellulose hydrogel were prepared using the procedures above, except cellulose was used instead of $\mathrm{CNC}$. The as-prepared hydrogel were immersed in distilled water for $24 \mathrm{~h}$ in order to remove any unreacted monomer. The dried hydrogel were prepared by drying the immersed hydrogel in an air circulation oven at $70^{\circ} \mathrm{C}$ for 2 days.

\section{ANALYSIS}

Transmission electron microscopy (TEM) was conducted using a Philips CM30 microscope to investigate the morphology and size of CNC. A droplet of diluted suspension was deposited onto a $\mathrm{Cu}$ grid covered with a thin carbon film. To enhance the contrast, the nanocrystals were negatively stained with 2 wt. \% uranyl acetate (a heavy metal salt) solution in deionized water for $1 \mathrm{~min}$ and then dried at room temperature.

Fourier transform infrared spectrum were recorded using a Perkin-Elmer FTIR spectrophotometer. Kenaf 
TABLE 1. Composition of hydrogel

\begin{tabular}{cccccc}
\hline Sample & CNC/Cellulose $(\mathrm{g})$ & AA $(\mathrm{g})$ & MBA $(\mathrm{mL})$ & APS $(\mathrm{mL})$ & Water $(\mathrm{mL})$ \\
\hline Neat AA & - & 5.00 & 10 & 1 & 25 \\
$1 \%$ & 0.05 & 4.95 & 10 & 1 & 25 \\
$2 \%$ & 0.10 & 4.90 & 10 & 1 & 25 \\
$3 \%$ & 0.15 & 4.85 & 10 & 1 & 25 \\
$4 \%$ & 0.20 & 4.80 & 10 & 1 & 25 \\
\hline
\end{tabular}

fibers before and after treatment along with hydrogel produced were analyzed. The samples were finely ground and mixed with potassium bromide, $\mathrm{KBr}$. The mixture was then compressed into pellet form. FTIR spectral analysis was performed within the wave number range of $400-4000$ $\mathrm{cm}^{-1}$.

Thermogravimetric analysis (TGA) was carried out with a TGA/SDTA $851^{\mathrm{e}}$ Mettler Toledo thermogravimetric analyzer in a nitrogen atmosphere for neat PAA, $2 \%$ and $4 \%$ of PAA/cellulose and PAA/nanocellulose hydrogel. The samples were heated from 50 to $800^{\circ} \mathrm{C}$ at $10^{\circ} \mathrm{C} \mathrm{min}$.

The equilibrium swelling percentage of hydrogel were investigated in various buffer solutions ranging from $\mathrm{pH} 3$ to 11 . The ionic strength was kept constant, $0.1 \mathrm{M}$. The dried hydrogel were cut into small pieces and immersed in $50 \mathrm{~mL}$ buffer solutions of desired $\mathrm{pH}$ and allowed to soak at predetermined time intervals. The percentage of swelling can be determined by weight differences method and is expressed in (1).

$$
\text { Swelling }(\%)=\frac{W_{f}-W_{i}}{W_{i}} \times 100 \% \text {, }
$$

where is the weight of swollen hydrogel and is the weight of dry gel.

\section{RESULTS AND DISCUSSION}

\section{TRANSMISSION ELECTRON MICROSCOPY (TEM)}

Figure 1 shows the TEM images of $\mathrm{CNC}$ extracted from kenaf fibers. The typical nanoscale needle like structure can be a clear visible evidenced of the effectiveness of acid hydrolysis to remove the amorphous region of cellulose leaving the crystal domain behind (Oliveira Taipina et al. 2013). The isolated CNC were around $200-250 \mathrm{~nm}$ long and 3-6 $\mathrm{nm}$ wide, giving the average aspect ratio in the range of 33-83.

\section{FOURIER TRANSFORM INFRA-RED}

The spectrum presented in Figure 2(a) shows the changes in chemical composition of kenaf fiber after chemical treatments and acid hydrolysis while Figure 2(b) is the FTIR spectrum for hydrogel. From Figure 2(a), the broaden peak of $\mathrm{OH}$ stretching at around 3650$3200 \mathrm{~cm}^{-1}$ is observed in all spectrum and the main spectral characteristics of fibers were found within the $900-1750 \mathrm{~cm}^{-1}$ range. The absence of the peak at 1734 $\mathrm{cm}^{-1}$ corresponds to $\mathrm{C}=\mathrm{O}$ bonds in carboxylic acid and ester components of hemicelluloses due to the removal

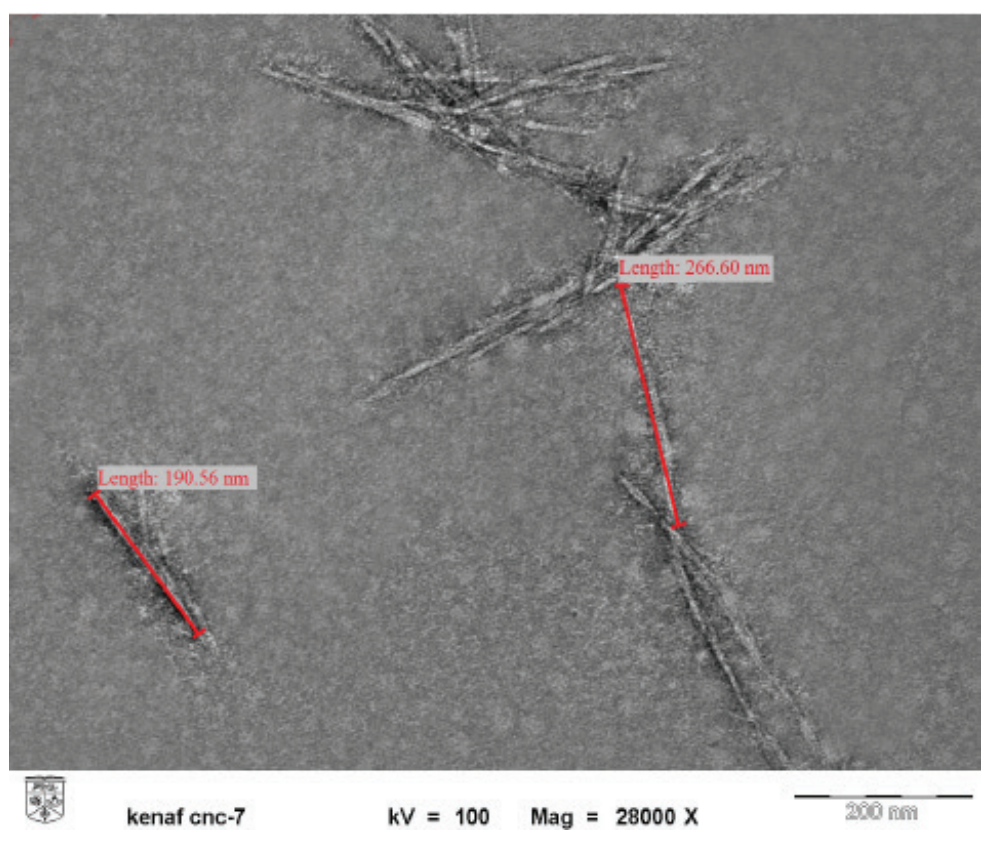

FIGURE 1. TEM images of CNC 


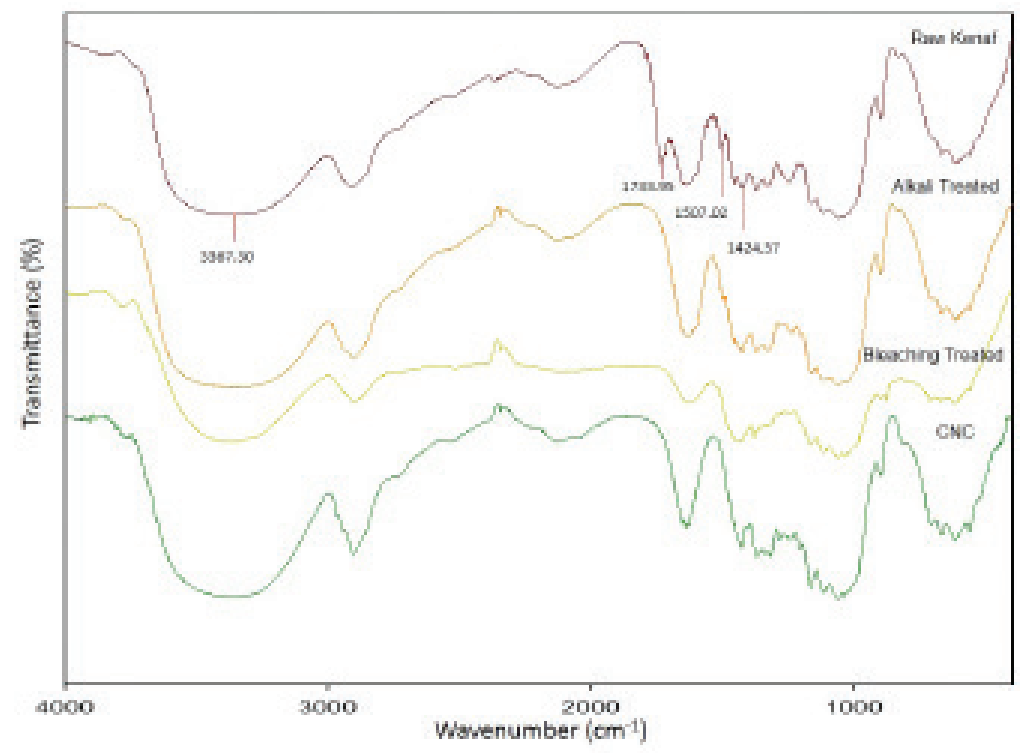

FIGURE 2(a). FTIR spectrum of raw kenaf fiber, alkali treated kenaf fiber, bleaching treated kenaf fiber and cellulose nanocrystals

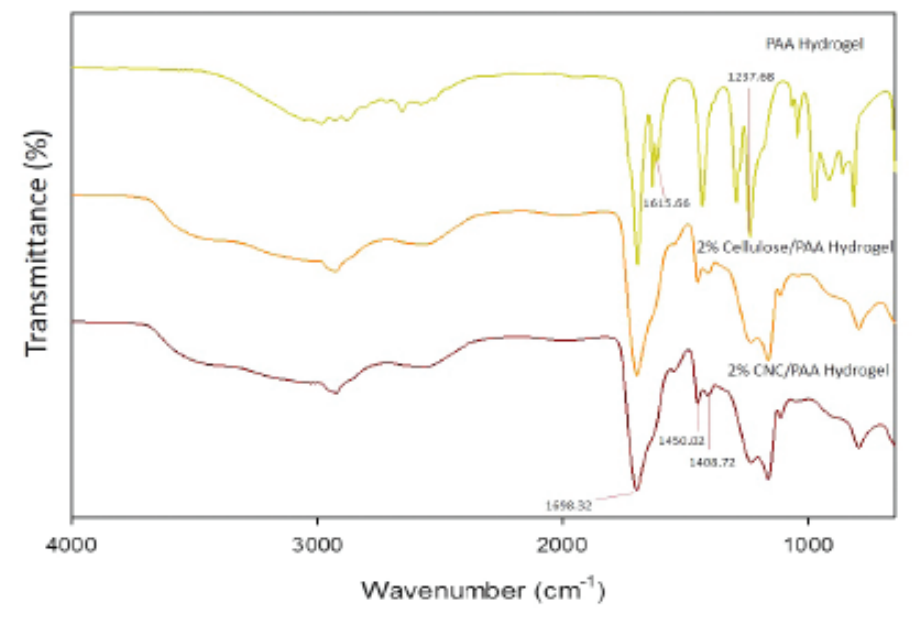

FIGURE 2(b). FTIR spectrum of pure PAA hydrogel, $2 \%$ cellulose/PAA hydrogel and $2 \% \mathrm{CNC} / \mathrm{PAA}$ hydrogel

of hemicelluloses after alkali treatment (Richard et al. 2014). The peaks at 1507 and $1424 \mathrm{~cm}^{-1}$ in the raw kenaf fiber assigned to $\mathrm{C}=\mathrm{C}$ stretch of aromatic rings of lignin were observed. The reduction in intensity of those absorbance peaks after alkali treatment and absence after bleaching treatment indicating lignin removal (Alemdar \& Sain 2008; Saha et al. 2010; Sawpan et al. 2011). From the spectrum of $\mathrm{CNC}$ and cellulose obtained, it can be concluded that the acid hydrolysis only affect the morphology of the cellulosic material and not their chemical structure (Spagnol et al. 2012). Similar results were obtained by Johar et al. (2012) and Kargarzadeh et al. (2012) using the same method of CNC extraction.

The acrylic acid spectrum exhibited peaks at 1235 , 1695 and $1615 \mathrm{~cm}^{-1}$ assigned to stretching vibration of $\mathrm{C}=\mathrm{O}$ and $\mathrm{C}-\mathrm{O}$ of carboxylate group and $\mathrm{C}=\mathrm{C}$ stretching. From the hydrogel spectrum, the bands at 1409 and
$1450 \mathrm{~cm}^{-1}$ are attributed to $\mathrm{C}-\mathrm{OH}$ bending vibration of PAA. The absence of $\mathrm{C}=\mathrm{C}$ stretching from hydrogel spectrum indicates the polymerization of acrylic acid into poly(acrylic acid), an indication supported by the finding that irradiation of acrylates with electrons leads to the curing of the polymer by the formation of radicals that initiate the polymerization and crosslinking reaction (Mohd Amin et al. 2012; Rahimi et al. 2012; Scherzer et al. 1997).

\section{THERMAL ANALYSIS}

Thermal stability studies provide useful information on the selection of materials with the best properties for specific applications. The thermograms obtained are presented in Figure 3. From the thermogram, the first decomposition of PAA can be attributed to the loss of 
residual water content; the second with a loss in mass from the release of $\mathrm{H}_{2} \mathrm{O}, \mathrm{CH}_{4}$ and the AA monomer at around $310^{\circ} \mathrm{C}$; and the third with a loss in mass between 350 to $480^{\circ} \mathrm{C}$ due to release of AA moieties consisting of short-chain fragments from main chain scission leaving around $15 \%$ residue. Comparing the three thermograms, the hydrogel underwent stages of decomposition similar to PAA. It is clearly showed that incorporation of cellulose and $\mathrm{CNC}$ into PAA had enhanced the thermal stability of the hydrogel, as evidence by the fact that the thermal degradation temperature of the hydrogel has shifted to a higher temperature as compared to PAA. This indicates a favorable interaction between the matrix and filler in the hydrogel structure leading to its increased stability. CNC/ PAA hydrogel showed even higher thermal stability as compared to cellulose/PAA hydrogel due to the presence of $\mathrm{CNC}$ in hydrogel network which had resulted in a more structured hydrogel (Bayramgil 2008; Bera et al. 2013; Cha et al. 2012; Mohd Amin et al. 2012).

\section{SWELLING TEST}

The swelling behavior of hydrogel was investigated in the $\mathrm{pH}$ range of 3 to 11 . PAA is a polyelectrolyte because it possess large amount of ionizable group. The pendant acidic group on PAA undergoes ionization just like acids group of monoacids at high $\mathrm{pH}$. From the swelling test result shown in Figure 4, the swelling ratio of all hydrogel reached an optimum at $\mathrm{pH} 7$ and decreased with further increase in $\mathrm{pH}$. The electrostatic repulsion between neighboring fixed charges of PAA drives for swelling. The low swelling ratios observed at $\mathrm{pH} 2$ can be assigned to the unfavorable condition for the $\mathrm{COOH}$ groups in PAA to ionize, whose $\mathrm{pKa}$ is 4.25 (Serpe et al. 2003). At $\mathrm{pH}$ above 4.25 , the swelling ratio increase drastically. When $\mathrm{pH}$ is further increased, the carboxylic group of PAA is deprotonated to a negatively charged carboxylate ion, with the resulting electrostatic repulsion caused the hydrogel to swell (Akala et al. 1998; Anirudhan \& Rejeena 2012; da Silva \& Ganzarolli de Oliveira 2007). The swelling

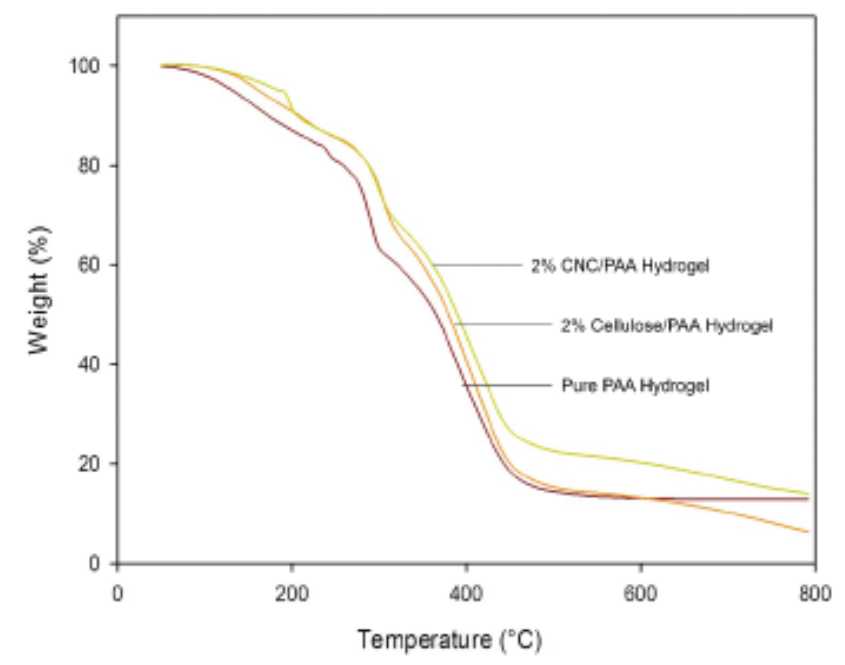

FIGURE 3. TGA thermogram of pure PAA hydrogel, $2 \%$ cellulose/PAA hydrogel and $2 \% \mathrm{CNC} / \mathrm{PAA}$ hydrogel

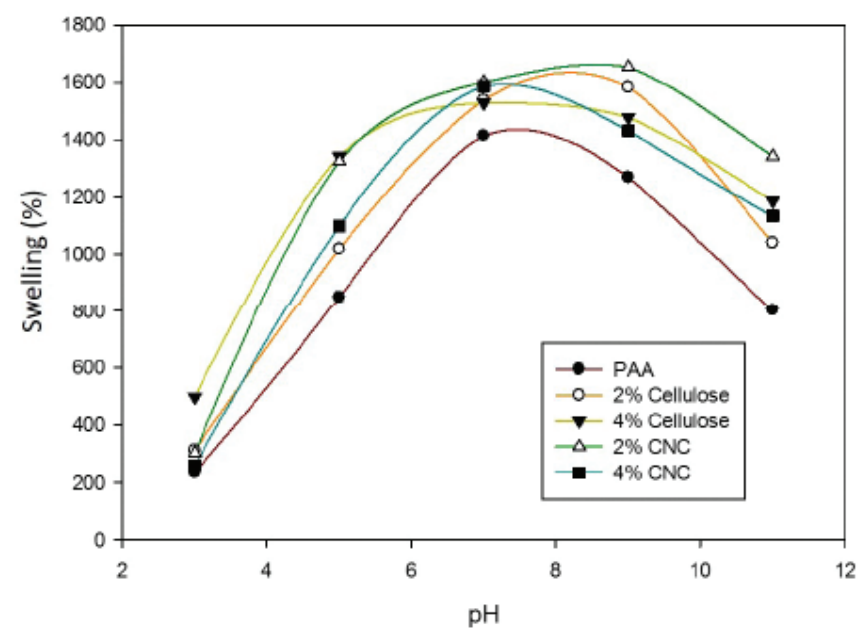

FIGURE 4. Swelling behavior of hydrogel 
ratio reached an optimum at $\mathrm{pH} 7$, further increase in $\mathrm{pH}$ caused the swelling ratio to decline sharply. This is due to at $\mathrm{pH}>8$, most of $-\mathrm{COO}^{-}$groups change into $-\mathrm{COOH}$ groups due to excess of negatively charged groups in the media, which results in the decrease of repulsion among polymeric chains and consequentially leads to a decrease of liquid absorbency (Kim et al. 2004; Laftah \& Hashim 2013). The observed swelling trends of the hydrogel composite are fairly the same as PAA hydrogel which obtain maximum swelling at around $\mathrm{pH} 7$ and drastically drop at $\mathrm{pH} 11$. This shows that the cellulose or CNC did not contribute to the $\mathrm{pH}$ responsive property of the hydrogel. Both cellulose and CNC composite hydrogel showed higher swelling ratio as compare to pure PAA hydrogel due to the hydrophilic nature of cellulose and $\mathrm{CNC}$. This shows that introduction of cellulose and $\mathrm{CNC}$ into hydrogel network can subsequently increase the water uptake capacity and reduce the time needed for hydrogel to reach equilibrium.

\section{CONCLUSION}

In this study, $\mathrm{pH}$ responsive PAA/CNC hydrogel was synthesized by cross-linking AA monomer in CNC suspension using MBA as cross-linking agent. The resulting hydrogel showed optimum swelling at $\mathrm{pH} 7$ with higher swelling ratio compared to PAA hydrogel. The PAA/CNC hydrogel also showed higher thermal stability compared to PAA/cellulose and PAA hydrogel. This proved that nano size cellulosic material showed great potential as materials for improving swelling and thermal stability of hydrogel. Such PAA/CNC hydrogel with good swelling and smart $\mathrm{pH}$ responsive possess wide potential application in cutting edge technology areas.

\section{ACKNOWLEDGEMENTS}

The authors acknowledge the financial support from the Ministry of Science, Technology and Innovation (MOSTI) and Universiti Kebangsaan Malaysia (UKM) under Sciencefund grant 03-01-02-SF1106 and Zamalah Scheme of Research University (RU), respectively.

\section{REFERENCES}

Akala, E.O., Kopečková, P. \& Kopeček, J. 1998. Novel pHsensitive hydrogels with adjustable swelling kinetics. Biomaterials 19(11-12): 1037-1047.

Alemdar, A. \& Sain, M. 2008. Biocomposites from wheat straw nanofibers: Morphology, thermal and mechanical properties. Composites Science and Technology 68(2): 557-565.

Anirudhan, T.S. \& Rejeena, S.R. 2012. Poly(acrylic acid)modified poly(glycidylmethacrylate)-grafted nanocellulose as matrices for the adsorption of lysozyme from aqueous solutions. Chemical Engineering Journal 187: 150-159.

Arunbabu, D., Shahsavan, H., Zhang, W. \& Zhao, B. 2012. Poly(AAc-co-MBA) hydrogel films: Adhesive and mechanical properties in aqueous medium. The Journal of Physical Chemistry B 117(1): 441-449.

Bardajee, G.R., Pourjavadi, A., Ghavami, S., Soleyman, R. \& Jafarpour, F. 2011. UV-prepared salep-based nanoporous hydrogel for controlled release of tetracycline hydrochloride in colon. Journal of Photochemistry and Photobiology B: Biology 102(3): 232-240.

Bayramgil, N.P. 2008. Thermal degradation of [poly(Nvinylimidazole)-polyacrylic acid] interpolymer complexes. Polymer Degradation and Stability 93(8): 1504-1509.

Bera, A., Misra, R.K. \& Singh, S.K. 2013. Structural and behavioral characteristics of radiolytically synthesized polyacrylic acid-polyacrylonitrile copolymeric hydrogels. Radiation Physics and Chemistry 91: 180-185.

Bondeson, D., Mathew, A. \& Oksman, K. 2006. Optimization of the isolation of nanocrystals from microcrystalline cellulose by acid hydrolysis. Cellulose 13(2): 171-180.

Censi, R., Schuurman, W., Malda, J., Di Dato, G., Burgisser, P.E., Dhert, W.J.A., Van Nostrum, C.F., Di Martino, P., Vermonden, T. \& Hennink, W.E. 2011. A printable photopolymerizable thermosensitive p(HPMAm-lactate)-PEG hydrogel for tissue engineering. Advanced Functional Materials 21(10): $1833-1842$

Cha, R., He, Z. \& Ni, Y. 2012. Preparation and characterization of thermal/pH-sensitive hydrogel from carboxylated nanocrystalline cellulose. Carbohydrate Polymers 88(2): 713-718.

Chang, M., Chung, M., Lee, B.S. \& Kwak, C.H. 2006. Structure, magnetic and ion-exchange properties of self-assembled triaza-copper(II)-oxalate hybrides having nanoscale one-dimensional channel. Journal of Nanoscience and Nanotechnology 6(11): 3338-3342.

Da Silva, R. \& Ganzarolli de Oliveira, M. 2007. Effect of the cross-linking degree on the morphology of poly(NIPAAmco-AAc) hydrogels. Polymer 48(14): 4114-4122.

Flauzino Neto, W.P., Silvério, H.A., Dantas, N.O. \& Pasquini, D. 2013. Extraction and characterization of cellulose nanocrystals from agro-industrial residue - Soy hulls. Industrial Crops and Products 42: 480-488.

Habibi, Y., Lucia, L.A. \& Rojas, O.J. 2010. Cellulose nanocrystals: Chemistry, self-assembly, and applications. Chemical Reviews 110(6): 3479-3500.

Hellio, D. \& Djabourov, M. 2006. Physically and chemically crosslinked gelatin gels. Macromolecular Symposia 241(1): 23-27.

Henrique, M.A., Silvério, H.A., Flauzino Neto, W.P. \& Pasquini, D. 2013. Valorization of an agro-industrial waste, mango seed, by the extraction and characterization of its cellulose nanocrystals. Journal of Environmental Management 121: 202-209.

Huang, Y., Lu, J. \& Xiao, C. 2007. Thermal and mechanical properties of cationic guar gum/poly(acrylic acid) hydrogel membranes. Polymer Degradation and Stability 92(6): 1072-1081.

Janković, B., Adnađević, B. \& Jovanović, J. 2007. Application of model-fitting and model-free kinetics to the study of nonisothermal dehydration of equilibrium swollen poly (acrylic acid) hydrogel: Thermogravimetric analysis. Thermochimica Acta 452(2): 106-115.

Johar, N.,Ahmad,I. \& Dufresne,A. 2012. Extraction, preparation and characterization of cellulose fibres and nanocrystals from rice husk. Industrial Crops and Products 37(1): 93-99.

Kargarzadeh, H.,Ahmad, I., Abdullah, I., Dufresne, A., Zainudin, S. \& Sheltami, R. 2012. Effects of hydrolysis conditions on the morphology, crystallinity, and thermal stability of cellulose nanocrystals extracted from kenaf bast fibers. Cellulose 19(3): 855-866. 
Kim, S.J., Kim, H., Park, S.J. \& Kim, S.I. 2004. Shape change characteristics of polymer hydrogel based on polyacrylic acid/poly(vinyl sulfonic acid) in electric fields. Sensors and Actuators A: Physical 115(1): 146-150.

Kim, S.J., Lee, K.J., Lee, S.M., Kim, I.Y. \& Kim, S.I. 2004. Water behavior of poly(acrylic acid)/poly (acrylonitrile) semi-interpenetrating polymer network hydrogels. High Performance Polymers 16(4): 625-635.

Laftah, W.A. \& Hashim, S. 2013. The influence of plant natural fibers on swelling behavior of polymer hydrogels. Journal of Composite Materials 48(5): 555-569.

Liu, H., Wang, D., Shang, S. \& Song, Z. 2011. Synthesis and characterization of Ag-Pd alloy nanoparticles/carboxylated cellulose nanocrystals nanocomposites. Carbohydrate Polymers 83(1): 38-43.

Mohd Amin, M.C.I., Ahmad, N., Halib, N. \& Ahmad, I. 2012. Synthesis and characterization of thermo- and $\mathrm{pH}$-responsive bacterial cellulose/acrylic acid hydrogels for drug delivery. Carbohydrate Polymers 88(2): 465-473.

Needleman, I.G. \& Smales, F.C. 1995. In vitro assessment of bioadhesion for periodontal and buccal drug delivery. Biomaterials 16(8): 617-624.

Oliveira Taipina, M., Ferrarezi, M., Yoshida, I. \& de Gonçalves, M. 2013. Surface modification of cotton nanocrystals with a silane agent. Cellulose 20(1): 217-226.

Rahimi, N., Molin, D.G., Cleij, T.J., van Zandvoort, M.A. \& Post, M.J. 2012. Electrosensitive polyacrylic acid/fibrin hydrogel facilitates cell seeding and alignment. Biomacromolecules 13(5): 1448-1457.

Richard, B., Quilès, F., Carteret, C. \& Brendel, O. 2014. Infrared spectroscopy and multivariate analysis to appraise $\alpha$-cellulose extracted from wood for stable carbon isotope measurements. Chemical Geology 381: 168-179.

Saha, P., Manna, S., Chowdhury, S.R., Sen, R., Roy, D. \& Adhikari, B. 2010. Enhancement of tensile strength of lignocellulosic jute fibers by alkali-steam treatment. Bioresource Technology 101(9): 3182-3187.

Sahiner, N. 2013. Soft and flexible hydrogel templates of different sizes and various functionalities for metal nanoparticle preparation and their use in catalysis. Progress in Polymer Science 38(9): 1329-1356.

Sawpan, M.A., Pickering, K.L. \& Fernyhough, A. 2011. Effect of fibre treatments on interfacial shear strength of hemp fibre reinforced polylactide and unsaturated polyester composites. Composites Part A: Applied Science and Manufacturing 42(9): 1189-1196.

Scherzer, T., Beckert, A., Langguth, H., Rummel, S. \& Mehnert, R. 1997. Electron beam curing of methacrylated gelatin. I. Dependence of the degree of crosslinking on the irradiation dose. Journal of Applied Polymer Science 63(10): 1303-1312.

Serpe, M.J., Jones, C.D. \& Lyon, L.A. 2003. Layer-by-layer deposition of thermoresponsive microgel thin films. Langmuir 19(21): 8759-8764.

Sharifi, S., Blanquer, S.B.G., van Kooten, T.G. \& Grijpma, D.W. 2012. Biodegradable nanocomposite hydrogel structures with enhanced mechanical properties prepared by photocrosslinking solutions of poly(trimethylene carbonate)poly(ethylene glycol)-poly(trimethylene carbonate) macromonomers and nanoclay particles. Acta Biomaterialia 8(12): 4233-4243.
Sheltami, R.M., Abdullah, I., Ahmad, I., Dufresne, A. \& Kargarzadeh, H. 2012. Extraction of cellulose nanocrystals from mengkuang leaves (Pandanus tectorius). Carbohydrate Polymers 88(2): 772-779.

Shirsath, S.R., Patil, A.P., Patil, R., Naik, J.B., Gogate, P.R. \& Sonawane, S.H. 2013. Removal of Brilliant Green from wastewater using conventional and ultrasonically prepared poly(acrylic acid) hydrogel loaded with kaolin clay: A comparative study. Ultrasonics Sonochemistry 20(3): 914923.

Sorbara, L., Jones, L. \& Williams-Lyn, D. 2009. Contact lens induced papillary conjunctivitis with silicone hydrogel lenses. Contact Lens and Anterior Eye 32(2): 93-96.

Spagnol, C., Rodrigues, F.H.A., Pereira, A.G.B., Fajardo, A.R., Rubira, A.F. \& Muniz, E.C. 2012. Superabsorbent hydrogel composite made of cellulose nanofibrils and chitosan-graftpoly(acrylic acid). Carbohydrate Polymers 87(3): 2038-2045.

Varga, Z., Molnar, K., Torma, V. \& Zrinyi, M. 2010. Kinetics of volume change of poly(succinimide) gels during hydrolysis and swelling. Physical Chemistry Chemical Physics 12(39): 12670-12675.

Wang, W., Deng, L., Liu, S., Li, X., Zhao, X., Hu, R., Zhang, J., Han, H. \& Dong, A. 2012. Adjustable degradation and drug release of a thermosensitive hydrogel based on a pendant cyclic ether modified poly( $\varepsilon$-caprolactone) and poly(ethylene glycol)co-polymer. Acta Biomaterialia 8(11): 3963-3973.

Wen, O.H., Kuroda, S.I. \& Kubota, H. 2001. Temperatureresponsive character of acrylic acid and $\mathrm{N}$-isopropylacrylamide binary monomers-grafted celluloses. European Polymer Journal 37(4): 807-813.

Wu, N. \& Li, Z. 2013. Synthesis and characterization of poly(HEA/MALA) hydrogel and its application in removal of heavy metal ions from water. Chemical Engineering Journal 215-216: 894-902.

Yuk, S., Cho, S. \& Lee, H. 1992. Electric current-sensitive drug delivery systems using sodium alginate/polyacrylic acid composites. Pharmaceutical Research 9(7): 955-957.

Zhou, Y., Zhao, Y., Wang, L., Xu, L., Zhai, M. \& Wei, S. 2012. Radiation synthesis and characterization of nanosilver/ gelatin/carboxymethyl chitosan hydrogel. Radiation Physics and Chemistry 81(5): 553-560.

Zuidema, J.M., Pap, M.M., Jaroch, D.B., Morrison, F.A. \& Gilbert, R.J. 2011. Fabrication and characterization of tunable polysaccharide hydrogel blends for neural repair. Acta Biomaterialia 7(4): 1634-1643.

Faculty of Science and Technology

Universiti Kebangsaan Malaysia

43600 Bangi, Selangor Darul Ehsan Malaysia

*Corresponding author; email: gading@ukm.edu.my

Received: 15 January 2014

Accepted: 15 November 2014 